Lecture Notes in Mechanical Engineering

Muhammad Abbas Ahmad Zaini

Mazura Jusoh

Norasikin Othman Editors

Proceedings of the

3rd International

Conference

on Separation

Technology

Sustainable Design in Construction, Materials and Processes

Springer 


\title{
Heavy Metal Adsorbent of Carbon from Sago Liquid Biowaste for Sustainable Technology
}

\author{
Zainab Ngaini ${ }^{D}$, Rafeah Wahi ${ }^{D}$, Hasnain Hussain $(\mathbb{D}$, \\ Nurul Qhalila Bahrin, and Nur Hanani Hasana
}

\begin{abstract}
Sarawak is one of the world's largest exporter of sago flour, from which the processing leads to a generation of biowaste in a significant amount. Thus, utilization of the biowaste is crucial to create a zero-waste sago processing industry. In this work, the heavy metal adsorbent was prepared from sago activated sludge via microwave technology. Sago effluent was treated via an activated sludge process to produce biomass, followed by microwave pyrolysis and chemical activation using $\mathrm{NaOH}$. The efficiency of the adsorbent for adsorption of $\mathrm{Cr}, \mathrm{Pb}$ and $\mathrm{Zn}$ in aqueous solution was studied at $\mathrm{pH} 2$, contact time $(24 \mathrm{~h})$, adsorbent dosage $(0.2-1 \mathrm{~g} / 50 \mathrm{~mL})$, and initial concentration $(5-25 \mathrm{mg} / \mathrm{L})$. Physicochemical analyses showed that the adsorbent has an average pore size of $36.29 \mu \mathrm{m}$ and BET surface area of $471.1 \mathrm{~m}^{2} / \mathrm{g}$. The maximum removal of heavy metals was: $\mathrm{Pb}(89.8 \%), \mathrm{Cr}(47.0 \%)$ and $\mathrm{Zn}(18.4 \%)$ at adsorbent dosage $(1 \mathrm{~g} / 50 \mathrm{~mL})$, initial concentration $(5 \mathrm{mg} / \mathrm{L})$, mixing speed $(150 \mathrm{rpm})$ and contact time $(24 \mathrm{~h})$. The Langmuir and Freundlich isotherm studies showed that $\mathrm{Qe}$ for $\mathrm{Pb}$ removal by sludge activated carbon was $3.202 \times 10^{-3} \mathrm{mg} / \mathrm{g}$. The results indicated the potential application of sago activated carbon for the removal of heavy metals, especially $\mathrm{Pb}$ from wastewater. Further isotherm study for the occurrence of chemisorptions process could be beneficial, which at the same creating a zero-waste sago processing industry for sustainable technology.
\end{abstract}

Keywords Adsorption $\cdot$ Biowaste $\cdot$ Heavy metal $\cdot$ Microwave pyrolysis $\cdot$ Sago effluent $\cdot$ Sago waste

\section{Introduction}

Sago (Metroxylon sagu) is an indigenous plant of Sarawak, Malaysia and easily grown in freshwater swamps and tropical lowland forests. Malaysia is one of the largest producers of sago flour in the world with annual export est. 41,000-48,000

\footnotetext{
Z. Ngaini $(\varangle) \cdot$ R. Wahi $\cdot$ H. Hussain · N. Q. Bahrin · N. H. Hasana Faculty of Resource Science and Technology, Universiti Malaysia Sarawak, 94300 Kota Samarahan, Sarawak, Malaysia

e-mail: nzainab@unimas.my
} 